\title{
Using aquatic plant biomass from de-weeding in biogas processes-an economically viable option?
}

\author{
Carsten Herbes ${ }^{1 *} \mathbb{D}$, Vasco Brummer ${ }^{1}$, Sandra Roth ${ }^{2}$ and Markus Röhl ${ }^{2}$
}

\begin{abstract}
Background: Landscape maintenance in Germany today requires regular and extensive de-weeding of waterways, mostly to ensure water runoff and provide flood protection. The costs for this maintenance are high, and the harvested biomass goes to waste.

Methods: We evaluated the economic feasibility of using water plant biomass as a substrate in biogas generation. We set up a plausible supply chain, used it to calculate the costs of using aquatic water biomass as a seasonal feedstock to generate biogas, and compared it against maize silage, a standard biogas substrate. We also calculated the costs of using the aquatic biomass mixed with straw silage.

Results: Although subject to estimation errors, our results do show that it is economically feasible to use water plants as a seasonal feedstock in a biogas plant, even in markets where their disposal yields only moderate gate fees. Ensiling water plants with straw, however, incurs the added high price of straw and thus only yields a positive financial result if gate fees for water plant disposal are very high.

Conclusions: Water plant biomass need not remain an unwelcome by-product of de-weeding waterways. The funds for its costly disposal can be redirected to the biomass supply chain and support the profitable use of aquatic biomass as a seasonal feedstock in biogas plants. However, the legal status of material from de-weeding needs to be clarified before biogas operators can act. Further development of technology for harvesting aquatic biomass is also called for.
\end{abstract}

Keywords: Aquatic biomass, Aquatic macrophytes, Biogas, Cost, Value chain, Economic viability

\section{Background}

Biogas production in Europe, and especially in Germany, has attained levels that demand attention. By the end of 2015, more than 17,000 plants with an installed capacity of more than $8.7 \mathrm{GW}$ were operating in Europe; of these, almost 11,000 were in Germany [1]. The current level of subsidies and a switch to a tendering system however have led to a sharp decrease in the number of newly erected biogas plants in Germany [2].

Due to special incentives in the German Renewable Energy Act (REA), biogas plants in Germany use energy

\footnotetext{
* Correspondence: carsten.herbes@hfwu.de

${ }^{1}$ Hochschule für Wirtschaft und Umwelt Nürtingen-Geislingen, Institute for International Research on Sustainable Management and Renewable Energy (ISR), Sigmaringer Strasse 14, 72622 Nürtingen, Germany

Full list of author information is available at the end of the article
}

crops as their primary substrate. These crops represented $51 \%$ of the feedstock volume in 2015; moreover, almost three-quarters (73\%) of the energy crops employed were maize silage [3]. However, using land to produce energy over using it to produce food and the environmental impact of biogas production have sparked fierce debates [4], and these have led German legislators to limit the percentage of maize a biogas plant may use under the REA. This in turn has spurred increased efforts to find alternative feedstock that does not compete with food crops.

These efforts come at a time when the growth of water plants has become a costly problem, as operators of waterways face costs for de-weeding and disposing of aquatic biomass, much of it from the Elodea species (waterweeds) [5, 6]. The biomass from these aquatic 
macrophytes (plants large enough to be seen by the naked eye) has swollen in volume. Many of these plants, the so-called neophytes, are not originally domestic, so they are not well regulated by the local ecosystem. Their excessive growth not only upsets the local ecobalance but also impairs the use of rivers and lakes for sports and recreation [5]. It is hardly surprising, then, to find that local stakeholders, such as lake owners and municipalities, feel compelled to have the waterways cleared and the biomass taken to a service company such as a composting plant for disposal, both of which incur high costs.

A synergy would seem obvious. The biogas industry needs alternative feedstocks; the municipalities and private entities responsible for water body maintenance have large volumes of aquatic biomass to dispose of. What on the surface appears obvious, however, may not make sense economically. While research into the economic viability of different feedstocks has occupied a central place in the literature on biogas [7-16], the economics of using aquatic biomass have received almost no attention. Some studies have considered algal biomass [17-21], but algae are not comparable to the biomass obtained from de-weeding waterways. Aquatic biomass contains mainly macrophytes with long plant stems, meaning its biodegradability and the way it can be handled by biogas plants differ markedly from that of algae. The parameters under which it could prove economically viable to use aquatic biomass as a feedstock thus warrant their own investigation.

To do so, we conceptualized a realistic supply chain by which aquatic macrophyte biomass could be used as a feedstock in biogas production. We proceeded step-by-step in evaluating technologies currently used in de-weeding and biogas production. We compared these results to those found when using a standard biogas feedstock such as maize silage.

Our research questions were:

1. What are the necessary steps to produce, transport, pre-treat, and use aquatic biomass as a biogas substrate and to dispose of the digestate?

2. What are the estimated costs for each step applying current technology?

3. Is aquatic biomass, under the current circumstances, economically competitive compared with a standard input material like maize silage?

4. What supply chain costs impact most greatly the economic feasibility of using aquatic biomass in biogas generation?

We proceed as follows: In the next section, we introduce our material and methods, especially the different steps considered along the aquatic biomass supply chain.
We then present our results, followed by a discussion and conclusions.

\section{Methods}

We gathered data for this study as part of project "AquaMak"-Aquatic Macrophytes Economic and Ecological Ways of Use, a nationwide study in Germany to evaluate the use of aquatic biomass. The project included a nationwide email survey containing questions focusing on steps in a possible aquatic biomass supply chain. Further data was gathered by telephone and email interview surveys that targeted experts with knowledge of the different steps along the value chain. This included experts for farming machinery, agricultural contractors and machinery manufacturers, as well as biogas producers. Additional data was generated by extensive fermentation tests with regard to the potential of aquatic biomass to serve as a biogas substrate; this testing enabled us to determine pre-treatment requirements.

\section{Aquatic biomass supply chain}

Our model was designed to capture seven steps along the aquatic biomass supply chain, from cutting through use and disposal. The model distinguishes different existing pathways for the first two steps: cutting and collecting the biomass. The full seven-step supply chain appears in Fig. 1 and is described in the following paragraphs.

\section{S1. Cutting}

Cutting of aquatic macrophytes in German rivers and lakes is primarily carried out in two ways. The first entails use of a mowing bucket mounted to an excavator, a method suitable only for small streams that can be completely accessed by the excavator, whose mowing bucket is typically not more than a few meters wide. We did not consider this case representative for our study, as the biomass excavated in this manner contains too much non-organic material to be usable for biogas production. Also, in many cases, the biomass is not gathered but left at the stream banks to degrade.

The second option uses a boat-mounted cutting device (Fig. 2) that cuts aquatic weeds at a water depth of approximately 1.20 to $1.80 \mathrm{~m}$. The biomass produced with this process is relatively free from non-organic material and can be used in subsequent processes.

\section{S2. Collecting}

Methods for collecting the biomass depend on the machinery used for cutting and the condition of the water body:

a. When the boat that holds the cutting machinery is capable of holding a reasonable amount of biomass, 


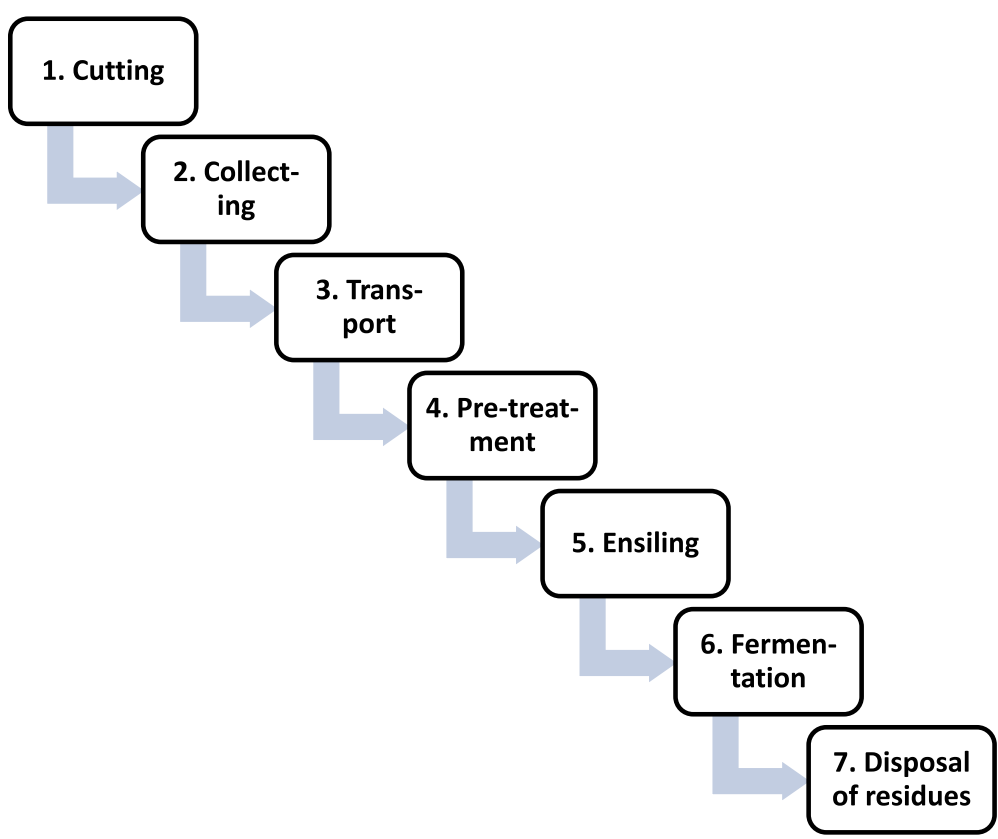

Fig. 1 Overview of the aquatic biomass supply chain

then direct collection is used. As the whole boat has to be quite large, this is mostly the case in big lakes that allow large boats to maneuver. These boats are equipped with a two-way conveyor belt capable of collecting the floating biomass as well as offloading it to shore.

b. A dedicated collecting boat is used when the water body is not large enough for a combined cuttingcollecting boat or when such a boat would be too cumbersome to be transported to the site. The different tasks of cutting and collecting can also be carried out by the same boat after changing the tools mounted to it.

c. Stationary collecting can be used when the waterbody has sufficient current and is capable of

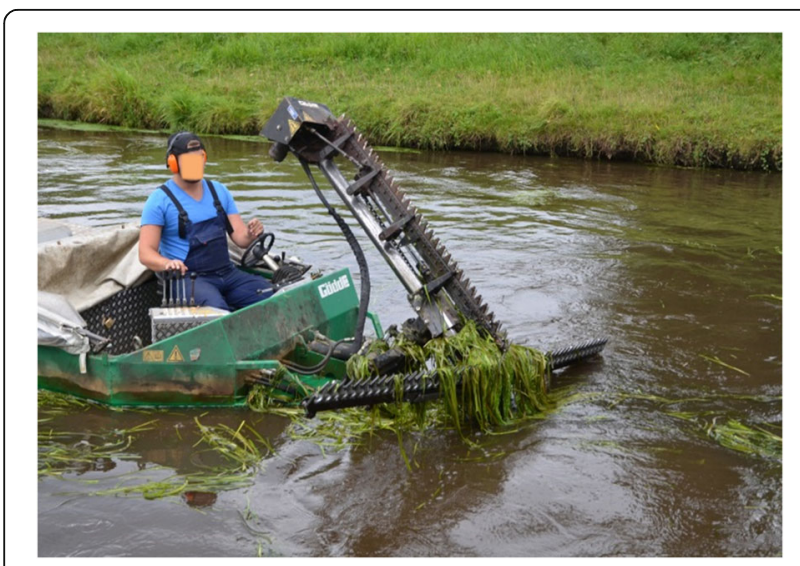

Fig. 2 Boat-mounted cutting device (source: Sandra Roth) transporting the biomass down to a stationary gathering post. Here, a simple rake is mounted across the stream to hold back the biomass, which is then extracted either by a stationary machine or an excavator.

\section{S3. Transport}

The fresh biomass has to be transported to be processed further. This poses a difficulty in the whole supply chain, as the biomass contains nearly $90 \%$ water. Letting the fresh biomass rest at the extraction site will reduce the water content but is not always possible. Furthermore, the liquid in the biomass contains organic matter with high energetic value. But fresh aquatic biomass has a relative low bulk density of, on average $250 \mathrm{~kg} / \mathrm{cbm}$ [22]. This mandates special transportation vehicles that can handle low-density organic matter at a reasonable cost (Fig. 3).

\section{S4. Pre-treatment}

Prior to being used in a biogas digester, the aquatic biomass has to be cleaned of impurities and pre-treated. This is due to the size and shape of the aquatic biomass, which consists mostly of long plant stems. These need to be cut into pieces for the digester and the feeding technology, which otherwise would clog. Also, any straw used needs to be pre-treated to avoid clogging [23]. All such pre-treatment processes rely on machinery not specifically built for the purpose, as there are no comparable farm crops in use today. Experimental testing showed that a feed mixer (Fig. 4) is capable of dealing 


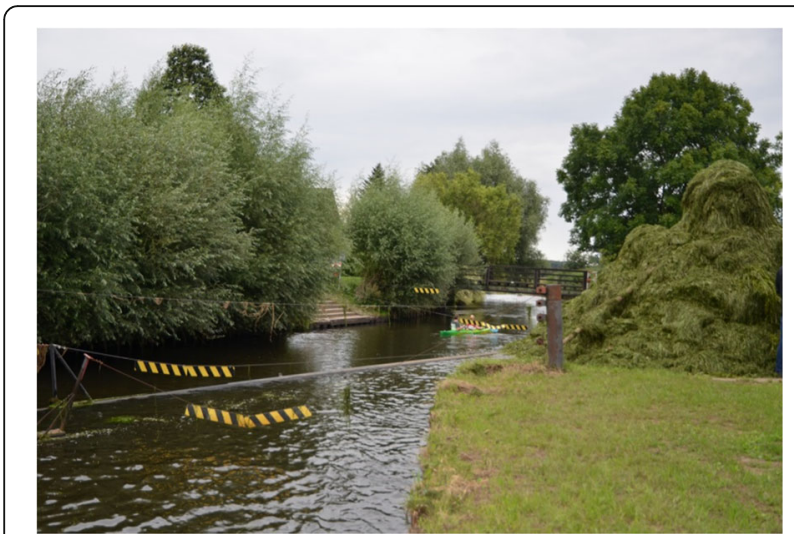

Fig. 3 Stationary collecting (source: Sandra Roth)

with aquatic biomass; another experimental approach in our project that showed promise was high-pressure water cutting.

\section{S5. Ensiling}

Aquatic biomass is a seasonal crop best cut in the months of June and September [24]. It has a low dry matter content [24] and a high rate of decomposition, making storage problematic as with feedstocks of similar characteristics $[25,26]$. To solve this problem, as part of the "AquaMak" project, a series of ensiling tests were carried out [27]. The results show that ensiling of aquatic biomass consisting of mainly Elodea ssp. is possible. The best results for ensiling were achieved by mixing the aquatic biomass with $50 \%$ shredded straw to act as structural material. This practice, however, incurs additional costs for the straw, and these have to be included when calculating the profitability of the resulting process.

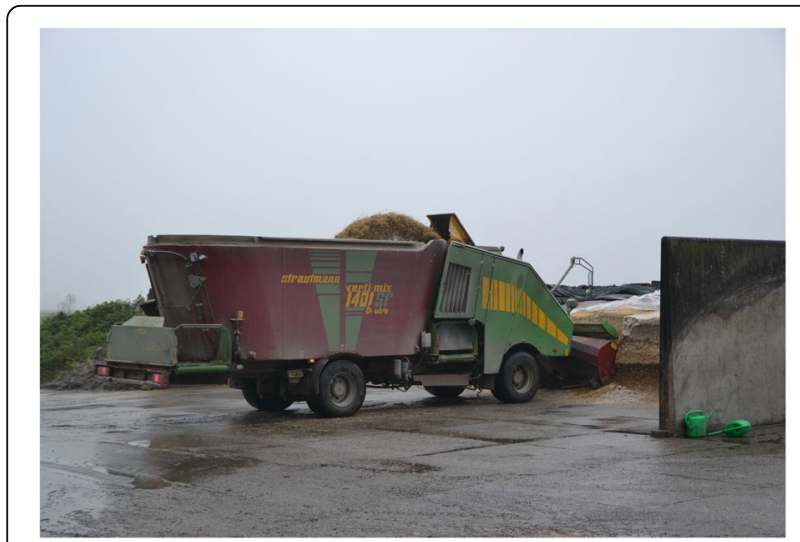

Fig. 4 Feed mixer (source: Barbara Benz)

\section{S6. Fermentation}

This is the step where biogas is actually produced through the anaerobic digestion of organic biomass. Pre-treated aquatic biomass is suitable for use in standard stirred biogas digesters, where it can replace other input material such as maize silage. The technical feasibility of using aquatic biomass this way was demonstrated in our project and also in earlier studies on Elodea [20, 24, 28]. It is the economic feasibility of the approach that we are interested in here. Our methods of doing so will be explained after considering the last step in the aquatic biomass supply chain.

\section{S7. Disposal of residues}

The material remaining after anaerobic digestion of a biodegradable feedstock is called digestate, and though it can serve as a valuable fertilizer, the marketing of digestate is in its infancy [29] and fermentation residues often have to be disposed of, and at considerable cost [30]. These costs are included in the last step of our calculation model. They can be higher in comparison to a process using standard materials such as maize silage, given the lower dry matter content of aquatic biomass, which leads to a higher throughput of material and thus higher quantities of residues. Disposal costs vary greatly depending on the region where the disposal site is located. We assume them to be 5 Euro/tonne which is within the range that Dahlin et al. found [30].

\section{Supply-chain cost model}

To assess the economic feasibility of using aquatic biomass as a replacement for maize silage in biogas production, we modeled a $500 \mathrm{~kW}$ biogas plant based on energy crops, a very common plant configuration in Germany [29]. In designing the model, we focused on three critical questions:

a. How much methane can be produced from aquatic biomass?

b. How much effluent (fermentation residue) is generated per cubic meter of methane?

c. Does a co-fermentation of mixed input materials lead to an incomplete fermentation that impacts the economics of biogas generation?

In thinking through these questions, we elaborated a multi-step Excel model to capture the seven steps presented above. By varying factors along the supply chain, we could perform a sensitivity analysis of the economic feasibility of using aquatic biomass to produce biogas. This allowed us to identify under what conditions it could be profitable to do so.

Calculating costs for the first five steps, from cutting to ensiling, is relatively simple. Costs incurred can be 
accumulated and then calculated as material costs per tonne of aquatic biomass. Modeling the effects of using aquatic biomass in the critical fermentation step and the potentially expensive disposal step cannot be calculated the same way. The processes are more complex, as the model has to capture the impact of using water plants on the digestion process.

Using Microsoft Excel, we built our model assuming Elodea nuttalii as the aquatic macrophyte and considering two cases: in the first, fresh Elodea nuttalii is used without adding other material; in the second, the material is ensiled and the silage consists of 50\% Elodea and $50 \%$ shredded straw. For each of these two input material options-pure Elodea or an Elodea/Straw mix - we calculate the impact on biogas production of using that option to replace $10 \%$ of the methane potential in the digester. The remaining $90 \%$ is assumed to be maize silage, the most important biogas substrate in Germany. In calculating how mixing feedstocks would affect biogas production, we consider four effects:

- First, using Elodea or a mix of Elodea and straw drives down the hydraulic retention time (HRT), or the average length of time that the feedstock remains in the digester, since the energy content (methane potential) of the material is much lower than that of maize.

- Second, the organic loading rate (OLR) increases at the same time because the share of organic material in Elodea that can be digested, aka its volatile solid (VS) content, is lower than that of maize silage. Both factors (HRT and OLR) impact the utilization of biomethane potential. To assess their impact, our model makes use of past research into the effect of increased OLRs and reduced HRTs on biomethane potential utilization.

- A third effect is the replacement of maize silage as a relatively cost-efficient material, with materials showing markedly different costs per cubic meter of biomethane potential.

- A fourth effect, albeit rather small, stems from the existing legal framework in Germany. Under the Renewable Energy Act (REA), the input material used in the biogas plant affects the feed-in-tariff (FIT) that the plant operator receives. Elodea from de-weeding is classified as waste input material under the German REA and so does not receive a biogas bonus.

Table 1 displays the configuration of input variables used in our model; the column labeled "Source" provides citations to the research from which the listed values derive.
We use negative cost figures to represent income received, modeled as the equivalent cost of disposal for the aquatic biomass that otherwise would be treated as waste. We assume that the biogas plant operator can charge for taking on aquatic biomass and these gate fees will offset the fees otherwise charged for disposal. The results from our questionnaire showed disposal costs of up to almost $180 €$ per tonne, depending on the geographical region. Our survey collected a total of 29 price points for disposal, of which 25 were under 100 Euro/ tonne. We excluded the four outliers above 100 Euro/ tonne and the average of the 25 price points under 100 Euro/tonne is $26.71 \mathrm{Euro} /$ tonne, which goes up to 45.12 if all price points are averaged. Podraza et al. report 66 Euro/tonne for the Hengstey Lake [31]. Our model assumes $30 \mathrm{Euro} / \mathrm{tonne}$ as disposal costs that can be turned into a gate fee by the biogas plant operator.

In order to estimate the effect of the changes in HRT and OLR on the utilization of the methane potential, we sought insight from the literature. The fermentation tests by Dahlhoff show almost no change in methane yield between OLRs of 3.4-3.7 $\mathrm{kg} \mathrm{VS} / \mathrm{cbm} /$ day [32]. Menardo et al. show that the OLR strongly influences the residual gas potential of plants using energy crops and manure, but the range of OLR values tested was much lower than Dahlhoff, from 0.85 to $2.25 \mathrm{~kg}$ VS/ $\mathrm{cbm} /$ day [33]. Gemmeke et al. show a link between HRT and residual gas potential; however, the magnitude of the effect in the range between 60 and 100 days is not clear [34]. The analyses by Lehner et al. also show no clear link between HRT and residual gas potential [35]. Taking a conservative approach, we assumed the utilization to be $98 \%$ for pure maize silage, $96 \%$ for maize plus Elodea, and 97\% for maize plus Elodea and straw.

Using these inputs, the Excel model calculates the cost of input material, logistics, disposal of digestate, and revenues for electricity production, as well as gross profit on the operator's balance sheet. The model does not consider other operator costs such as capital expenses or labor costs, since we assume those do not vary with substrate mix.

\section{Data collection \\ Questionnaire}

Our first approach to collect data for steps 1 through 3 was to ask organizations dealing with water plant management for the costs they incur in harvesting and disposing of the aquatic biomass. The questionnaire was sent to organizations in Germany associated with water maintenance. This included public authorities in all Federal States as well as private proprietors or tenants of lakes. Additionally, the questionnaire was sent to service providers offering water 
Table 1 Input variables

\begin{tabular}{|c|c|c|c|}
\hline Variable & Unit & Value & Source \\
\hline Electrical power & kWe & 500 & {$[2]$} \\
\hline Full load hours & h/a & 8000 & {$[56,57]$} \\
\hline Electrical efficiency & $\%$ & 40 & {$[58-63]$} \\
\hline Digester volume & Cubic meter (cbm) & 2570 & {$[64]$} \\
\hline $\begin{array}{l}\text { Year of commissioning } \\
\text { Dry matter (DM) content }\end{array}$ & Year & 2010 & $\begin{array}{l}\text { We assume that the plant } \\
\text { is in its sixth year of operation }\end{array}$ \\
\hline DM of maize silage & $\%$ & 34 & {$[65,66]$} \\
\hline DM of Elodea silage & $\%$ & 7 & {$[27]$} \\
\hline DM of Elodea-straw mix silage & $\%$ & 30 & {$[27]$} \\
\hline Volatile solids maize silage & $\%$ of $\mathrm{DM}$ & 95 & {$[67]$} \\
\hline Volatile solids Elodea silage & $\%$ of DM & 80 & [24], for fresh material not silage \\
\hline Volatile solids Elodea-straw mix silage & $\%$ of $\mathrm{DM}$ & 90 & Estimation \\
\hline Methane potential of maize silage & $\begin{array}{l}\mathrm{cbm} / \text { tonne fresh } \\
\text { matter (FM) }\end{array}$ & 110 & {$[3,62,67-70]$} \\
\hline Methane potential of Elodea silage & cbm/tonne FM & 15 & [27] \\
\hline Methane potential of Elodea-straw mix & $\mathrm{cbm} /$ tonne FM & 50 & {$[27]$} \\
\hline Feed-in-tariff for energy crops & EUR/kWhe & 0.20 & $\begin{array}{l}\text { [71]; we used the RESA } 2009 \text { since } \\
\text { the number of newly erected biogas } \\
\text { plants reached a peak during } \\
2009-2011\end{array}$ \\
\hline Feed-in-tariff for waste & EUR/kWhe & 0.13 & [71]; RESA 2009 \\
\hline $\begin{array}{l}\text { Disposal cost for aquatic biomass } \\
\text { (biogas plant gate fee) }\end{array}$ & EUR/tonne & 30.00 & Based on our survey \\
\hline Disposal cost for digestate & EUR/tonne & 5.00 & {$[32]$} \\
\hline Cost of maize silage (fresh matter) & EUR/tonne & 40 & {$[38,63,70,72,73]$} \\
\hline Cost of straw (fresh matter) & EUR/tonne & 81.41 & {$[74]$} \\
\hline Calorific (heating) value of methane & $\mathrm{kWh} / \mathrm{cbm}$ & 9.97 & {$[75]$} \\
\hline Utilization percentage of methane potential & $\%$ & $\begin{array}{l}98^{\mathrm{a}} \\
96^{\mathrm{b}} \\
97^{\mathrm{c}}\end{array}$ & Estimations based on [34] \\
\hline Digestate/input ratio & $\%$ & 85 & {$[76-79]$} \\
\hline
\end{tabular}

${ }^{\text {aPure maize silage }}$

${ }^{\mathrm{b}} 10 \%$ of methane potential from Elodea

${ }^{\mathrm{c}} 10 \%$ of methane potential from Elodea/Straw

maintenance services; these were identified through an internet search and the responses from water maintenance authorities. A total of 1123 questionnaires were sent out, for which we received 408 answers, giving a response rate of $36.3 \%$.

The questionnaire was part of the Research project "AquaMak" and included the following groups of questions related to this study:

1. What costs are incurred in the (yearly) maintenance of the river/lake?

2. How are these costs distributed among
a. Cutting
b. Collecting
c. Disposal

After evaluating the first datasets, it became clear that reported costs varied widely and, in many cases, could not be accurate. The quantities of harvested water plants were often no more than ballpark estimates. Moreover, responses were often given as aggregated maintenance costs only, with the distribution of these costs across steps left unspecified. We realized this was not terribly surprising, as public authorities or recreational business proprietors often contract out such work, the same way they contract out other maintenance work, so only know the aggregate numbers. As for the service groups with the detailed numbers, they are the contracted firms and would likely consider their raw expense figures to be proprietary. 


\section{Telephone interviews}

To enhance the quality of the data gathered by the questionnaire, a follow-up series of telephone interviews was carried out. Our goal was not only to supply details missing from the questionnaire results but also to correct inconsistent data. We did this by calling all respondents who had provided cost data and asking them to double-check their figures and break the costs down. In the phone interviews, it became clear that in most cases additional details simply were not available.

\section{Additional data}

To achieve a complete dataset for all parts of the biomass input chain, we used desk research to solicit the input of industry experts. By email and telephone contact with experts in water maintenance and machinery construction, better estimates for the capital cost of equipment and use could be obtained. In the end, we were able to develop a reasonably comprehensive business model for water maintenance.

\section{Results}

While aquatic macrophyte biomass from de-weeding of rivers and lakes can be used in many ways, our focus is on its use as a biogas substrate. In modeling the biomass supply chain, we sought to select technologies closely similar, if not identical, to those currently available for large-scale use. In this way, model results should align well with practicable real-world business models that can be realized by plant operators and investors. Further optimizations in harvesting, handling, and processing should bring these costs down, and so make biogas production from aquatic biomass increasingly feasible.

\section{Cutting and collecting}

Costs for cutting and collecting were calculated based on use of a small weed-cutting boat with front-mounted machinery, in our example the Berky 6410 type (www.berky.de) which is frequently used. This machine currently rents for $54 €$ per working hour (www.rent-a-berky.de). Based on calculations by Schulz [36] and applying a bulk density of 0.25 , such a boat can harvest around 3.3 tonnes of water plants per working hour yielding cost of $16.40 €$ per tonne of fresh matter for renting the equipment which is equivalent to capital cost if the boat was owned by the operator. Based on data from [36] (2017), a machine of this type should be able to cut $1 \mathrm{~m}^{3}$ of water weed at an operating cost (human resources, diesel) of $3.82 €$, resulting in a cost of $15.28 €$ per tonne of fresh matter, again assuming a bulk density of 0.25 . The total cost (capital cost of $16.40 €$ plus operating cost of $15.28 €$ ) is thus $31.68 €$ per tonne of fresh matter. This example is calculated for a heavily grown lake with mostly Elodea nuttallii as water weed and using one boat that alternates between using the cutting and collecting tools. With larger devices, such as a weed harvester, operating costs can be cut nearly by half [36], but capital costs will of course also increase.

\section{Transport}

Transport of aquatic biomass can be realized in many different ways, according to the characteristics of the transport equipment, availability of equipment, or access to the waterfront. We choose to model a typical tractor-drawn, double trailer. This allows for the transport of 14 tonnes per trailer, assuming the fresh matter fits in the trailer. According to data from KTBL Field Work calculator [37] provided by the German Association for Technology and Structures in Agriculture, this would result in a transport cost of $0.18 €$ per kilometer per metric tonne of fresh matter (Euro/tonne FM/ km) of maize. We compare these results to other research covering transportation costs for biogas feedstock in Table 2 and the cost generated by the KTBL Work calculator seem to be at the lower end. Bear in mind that estimates vary widely by source, and the transport costs are all given for maize.

We assume a distance of $20 \mathrm{~km}$ between the biogas plant and the water body where the Elodea is cut. At greater distances, the optimal transport technology will change, e.g., to trucks instead of tractors [38], and we wanted to develop a specific business model that could be used to reflect local business synergies.

Since the bulk density of Elodea is only half that of maize $(0.25$ versus $0.5 \mathrm{t} / \mathrm{cbm})$, we double the tractor-based transport cost to 0.37 Euro/tFM $/ \mathrm{km}$ which results in total transport cost of 7.40 Euro/tFM for a distance of $20 \mathrm{~km}$. Given that the KTBL cost approach seems to be at the lower end of cost data from the literature, actual cost for transporting Elodea could also be higher than our estimate.

\section{Pre-treatment}

Before it can be further processed, the fresh matter needs to be chopped to avoid clogging the biogas plant later. This also greatly improves the digestibility of the biomass, as has been proven for seaweed macro algae [39]. A variety of different pre-treatment technologies are available for biogas substrates, starting with rather simple physical technologies such as fodder mixing machines or extruders, but also including thermal technologies and chemical as well as biological treatment, e.g., with enzymes [40, 41]. These treatments are used to avoid clogging the digester, reduce the energy for stirring the digester content, and to increase methane yield.

Podraza et al. showed [31] that a fodder mixing machine, a rather simple technology, is capable of doing 
Table 2 Transport costs for biogas feedstock

\begin{tabular}{|c|c|c|c|c|}
\hline Material & Transport equipment & $\begin{array}{l}\text { Bulk density }[\mathrm{t} / \mathrm{cbm}] \\
\text { depending on water content }\end{array}$ & $\begin{array}{l}\text { Transport cost } \\
\text { [EUR/tFM/km] }\end{array}$ & Source \\
\hline Maize silage & No details available & No data & 0.13 & [80] \\
\hline Maize (fresh matter) & Agricultural tractor and trailer $\left(25 \mathrm{~m}^{3}\right)$ & 0.35 & 0.48 & {$[81]$} \\
\hline Maize (fresh matter) & Agricultural tractor and trailer $\left(25 \mathrm{~m}^{3}\right)$ & $0.35-0.7$ & 0.36 & {$[82,83]$} \\
\hline Maize fresh matter & Agricultural tractor and trailer $\left(40 \mathrm{~m}^{3}\right)$ & $0.35-0.7$ & 0.29 & [82] \\
\hline Food residues & No details available & & 0.03 & {$[80]$} \\
\hline
\end{tabular}

the task. Taking into account cost per cubic meter of mixed material in various fodder mixing machine types delivered by KTBL [42] and the prices provided by agricultural machinery pools as well as the experience that the Ruhrverband made with pre-treating water plants using a fodder mixing machine, we set the mixing cost at 15 Euro per tonne. Since this does not include removing impurities, such as waste dumped into lakes, pre-treatment cost may increase.

\section{Ensiling}

Given the low dry matter content of aquatic biomass and the fact that a biogas plant would only use small volumes of it, we assume the operator uses pure aquatic biomass only as a seasonal crop without ensiling and conserves the water plant-straw mix by using tube ensiling $[43,44]$, which is also used for other non-standard biogas input materials such as sugar beet pulp. We used a cost of 4 Euro/tonne of material, which is within the range of costs provided in the literature (see Table 3).

\section{Fermentation}

The changes in HRT and OLR are displayed in Table 4 where you see that the HRT decreases markedly when replacing maize by Elodea for $10 \%$ of the biomethane potential, whereas the OLR does not increase dramatically in the two replacement cases.

The fact that water plants are considered waste leads to slightly lower feed-in-tariffs under the German REA. For case 2, the FIT are $4 \%$ lower than in case 1 and in case 3 , they are $1 \%$ lower. As we assumed the increased OLR resulted in a lower methane potential yield, slightly more input material is required to achieve the same volume of methane production. One marked difference between case 3 and case 1, however, is the cost of the straw being used. Straw prices differ between regions, resulting in a cost increase of 52.65 Euro/tonne Elodea for case 3 over case 1 . Case 2, however, results in a cost

Table 3 Ensiling costs from the literature

\begin{tabular}{llll}
\hline Material & Ensiling technology & Cost [EUR/t] & Source \\
\hline Sugar beet pulp & Tube ensiling & $2.87-3.32$ & {$[84]$} \\
Chopped sugar beets & Tube ensiling & 6.48 & {$[85]$} \\
\hline
\end{tabular}

decrease of 0.19 Euro/tonne Elodea. The derivation of these cost deltas is discussed in the following.

\section{Waste disposal}

The treatment of waste disposal enters into our model calculations in two ways: as income generated for accepting the aquatic biomass (gate fees) and as expense incurred for disposing of the biogas digestate. As discussed in step seven (S7) of the methodology used to construct the biomass supply chain model, we elected to use a gate fee of 30 Euro per metric tonne in our model.

Table 5 lists the waste disposal costs so calculated for the three cases examined. Line 3 lists the gate fee revenue, while line 5 shows the additional disposal costs. We have not assumed any recovery of costs through sale of the digestate, although it does have fertilizer value. So the numbers shown depict the case where all the digestate must be disposed of.

In case 2, a mix of $90 \%$ maize and 10\% Elodea, the biogas plant can generate a sizeable revenue of EUR 208,333 through gate fees. In case 3 , the high methane potential of the straw drives down the amount of Elodea used and consequently also the gate fees. Line 6 shows that despite the higher disposal expenses incurred in cases 2 and 3, both still yield income for the plant operator.

\section{Total cost of producing methane from aquatic biomass}

Economic analysis of the total cost of generating methane from aquatic biomass depends on the reasons for its harvesting. In the first case, harvesting of biomass occurs through the de-weeding done to maintain a waterway; then, only the steps after transport are relevant for economic analysis because the agency responsible for the maintenance has to bear the costs for cutting, collecting, and transport whether the biomass is used as substrate or not.

In the second case, harvesting is done for the purpose of obtaining biogas feedstock; then, all steps in the value chain enter into an economic analysis and the costs of cutting, collecting, and transport of aquatic biomass have to be compared against those incurred for standard input material such as maize silage. Moreover, in this case, the biogas plant cannot generate income from gate 
Table 4 Effects on using Elodea on HRT and OLR

\begin{tabular}{llll}
\hline Item & Case 1: maize silage 100\% & $\begin{array}{l}\text { Case 2: maize silage 90\%, } \\
\text { Elodea 10\% }\end{array}$ & $\begin{array}{l}\text { Case 3: maize silage 90\%, } \\
\text { Elodea/straw mix silage 10\% }\end{array}$ \\
\hline HRT & 101 & 61 & 89 \\
OLR & 3.5 & 3.67 & 3.74 \\
\hline
\end{tabular}

fees. Table 6 summarizes the additional costs a biogas plant operator would incur in these steps per tonne of ensiled Elodea.

Under the assumptions outlined in the "Methods" section, using a silage of a mix of Elodea and straw (case 3) is not economically feasible. Pure Elodea (case 2), however, results in a clear financial advantage of 11.40 Euro/ tonne if necessary maintenance costs already cover cutting, collecting, and transporting the Elodea. If it is cut only for the purpose of using it in the biogas process, the costs for cutting, collecting, and transport have to be allocated to the Elodea silage as well and there is no gate fee because the organization responsible for water management would not have had to dispose of it. This makes its use $57.68 \mathrm{Euro} /$ tonne more expensive than using maize silage.

Table 7 applies the analysis to our model $500 \mathrm{~kW}$ biogas plant, showing the gross profit potential of the two Elodea cases considered. The calculation only shows those positions that are affected by the change in feedstock. Therefore, positions such as capital cost for investments for the biogas plant or human resources are not included. The cost of inputs listed are all in, meaning the gate fee for Elodea and the ensiling costs for case 3 are included in that line. The results show that using Elodea as a seasonal feedstock to replace 10\% of the methane potential of the input material leads to an increase in gross profit for this plant configuration of EUR 79,144 , whereas employing an Elodea-straw mix leads to a decrease of EUR 67,712.

Line 6 of Table 7 replicates line 1 of Table 5 and shows how the straw content in case 3 leads to an almost sevenfold decrease in the amount of Elodea used as compared to case 2. Gate fees-the principal income driver in our business model-are cut commensurately, and biogas generation-the fermentation step-changes from a modest income source in case 2 to significant expense for straw in case 3. Line 7 of Table 7 ties the per tonne figures in Table 6 to the figures for the model $500 \mathrm{~kW}$ plant. Note the contrasting sign conventions between the two.

Table 8 presents the figures from Table 7 recalculated to per MWh, a ratio that is frequently used in energy economics.

\section{Discussion and conclusions \\ Practical implications}

We sought to analyze the economic feasibility of using aquatic macrophyte biomass as an alternative feedstock for biogas production. Our results indicate that feasibility depends critically on two factors: first, the current disposal costs for the aquatic biomass, which we have reasoned could be paid as gate fees to a biogas plant operator for accepting the biomass as readily as they would be paid to the current disposal service. The second factor is the accounting treatment of the costs for cutting, collecting, and transporting the biomass. If these costs are liabilities that the waterway maintenance authority already carries, regardless of what is done with the biomass, then obviously the costs do not have to appear on the operator's balance sheet. If they represent expenses that have to be added to the profitability equation for the biogas plant, then an entirely different forecast emerges.

Under no conditions analyzed does the use of aquatic biomass from macrophytes mixed with straw (case 3) prove economically feasible. The income from gate fees is too low, and the added expense for biogas generation is too high, which together amounts to a lose-lose proposition for a biogas operator.

Table 5 Waste disposal cost

\begin{tabular}{|c|c|c|c|c|}
\hline & & $\begin{array}{l}\text { Case } 1 \\
\text { Maize silage 100\% }\end{array}$ & $\begin{array}{l}\text { Case } 2 \\
90 / 10 \text { Maize to Elodea }\end{array}$ & $\begin{array}{l}\text { Case } 390 / 10 \\
\text { Maize to Elodea/straw mix }\end{array}$ \\
\hline 1 & Amount of Elodea taken on [tFM] & 0 & 6944 & 1031 \\
\hline 2 & Amount of digestate [tFM] & 7885 & 13,147 & 8922 \\
\hline 3 & Avoided Elodea disposal cost = gate fee [EUR] & 0 & 208,333 & 30,928 \\
\hline 4 & Disposal cost for digestate [EUR] & 39,425 & 65,735 & 44,611 \\
\hline 5 & Disposal cost delta (case 2 vs. 1; case 3 vs. 1) & 0 & 26,310 & 5186 \\
\hline 6 & Net income/(loss) (row 3-row 5) & 0 & 182,023 & 25,472 \\
\hline
\end{tabular}


Table 6 Cost overview per tonne of Elodea used (all figures in €/tonne)

\begin{tabular}{lll}
\hline Step & $\begin{array}{c}\text { Case } 2 \\
\text { Elodea }\end{array}$ & $\begin{array}{c}\text { Case } 3 \\
\text { Elodea and straw mix }\end{array}$ \\
\hline 1. Cutting & 31.68 & \\
2. Collecting & & \\
3. Transport & 7.40 & 30.00 \\
4. Pre-treatment & 15.00 & 8.00 \\
5. Ensiling & 0.00 & 52.65 \\
6. Fermentation (negative value = cost saved) & -0.19 & 5.03 \\
7. Fermentation residue disposal & 3.79 & -30.00 \\
8. Elodea gate fee to offset disposal cost (income) & -30.00 & 65.68 \\
9. Total for lines 4-8 loss/(profit) & -11.40 & $134.76^{\mathrm{a}}$ \\
10. Total for lines 1-7 loss/(profit) & 57.68 & \\
\hline
\end{tabular}

${ }^{a}$ In case the Elodea is harvested only for the purpose of using it in a biogas plant, the water body owner does not save disposal cost and therefore would not be ready to pay a gate fee. Therefore, the gate fee cannot be subtracted in this case

If disposal costs, translated into gate fees, are reasonable (30€/tonne) and the costs for the first three line items in the value chain are carried by the waterway authority, then our model predicts using Elodea as a seasonal feedstock to replace $10 \%$ of the methane potential of the input material (case 2) can boost the profits of a $500 \mathrm{~kW}$ biogas plant by more than $20 \%$.

Without gate fees, or if the costs for cutting, collecting, and transporting the biomass have to be carried on the operator's balance sheet, then aquatic biomass from macrophytes, with or without straw, cannot compete with established feedstock such as maize silage.

These results point to the need for a substantial process optimization if aquatic plants are to play a bigger role in the future of the biogas sector. It would only make sense for operators to carry the costs for getting the biomass out of the waterway and into the plant if those costs were scaled down dramatically. To illustrate, to offset these costs in the best of our two cases, line 10 of Table 6 shows the costs would have to come down at least $28 €$ per tonne, and probably down 30 . That is cutting the current costs of $39.08 € /$ tonne by more than $75 \%$ before harvesting aquatic biomass directly for biogas production becomes economically feasible. Cutting the raw material and accessing it from land is slow and uneconomical, and transport restrictions limit the use of the material to the geographical region around the harvesting site.

To set up a complete supply chain, there are more practical hurdles to be overcome, mainly in handling and preparing the biomass. Ensiling aquatic biomass without adding any material of higher dry matter content, such as straw, is technically difficult, since the biomass becomes liquid when ensiled [27]. Yet, it is the straw content of the mix that drives down the income potential from gate fees and drives up the fermentation costs for using Elodea.

Another practical impediment for biogas plant operators in Germany is the legal classification of aquatic biomass under the German REA and waste legislation. Depending on the commissioning year of the biogas plant, the use of aquatic biomass may not just influence the feed-in-tariff for the share of energy produced from this fraction of the input material, but may also put at risk the energy crop bonus for the remainder of the input material. Moreover, the entire digestate volume may have to be subjected to a costly hygienization process.

The legal classification under the REA could be clarified by the "Clearingstelle" (clearing institution), an institution run by the Federal Ministry for Economic Affairs

Table 7 Gross profit calculation for the model 500 kW biogas plant [EUR/a]

\begin{tabular}{llll}
\hline Item & Case 1 & Case 2 & Case 3 \\
& Maize silage 100\% & $90 / 10$ Maize/Elodea & $90 / 10$ Maize/Elodea-straw mix \\
\hline 1. Revenues from feed-in-tariff & 797,600 & 768,739 & 793,586 \\
2. Cost of input material, all in & 371,058 & 236,742 & 429,570 \\
3. Cost of digestate disposal & 39,425 & 65,735 & 44,611 \\
4. Gross profit p.a. & 387,118 & 466,262 & 319,405 \\
5. Gross delta profit/(loss) & 0 & 79,144 & $(67,713)$ \\
6. Elodea taken on [tFM] & 0 & 6944 & 1031 \\
7. Per tonne profit/(loss) (5 -6) & 0 & 11.40 & -65.68 \\
\hline
\end{tabular}


Table 8 Gross profit calculation for the model 500 kW biogas plant [EUR/MWh]

\begin{tabular}{llll}
\hline Item & Case 1 & Case 2 & Case 3 \\
& Maize silage 100\% & $90 / 10$ Maize/Elodea & 90/10 Maize/Elodea-straw mix \\
\hline 8. Revenues from feed-in-tariff & 200 & 193 & 199 \\
9. Cost of input material, all in & 93 & 59 & 108 \\
10. Cost of digestate disposal & 10 & 16 & 11 \\
11. Gross profit p.a. & 97 & 117 & 80 \\
12. Gross delta profit/(loss) & 0 & 20 & $(17)$ \\
\hline
\end{tabular}

and Energy [45]. Today, however, it would represent an unjustifiable risk from any sensible risk-reward perspective for a biogas plant operator to use aquatic macrophyte biomass as feedstock. Therefore, future amendments to the REA should make the classification of this material clear; were the classification status amended from "waste" to "landscape conservation material," the ensuing bonuses would certainly be helpful in developing this promising biomass stream.

\section{Sensitivities}

The business model we have developed, and the economic results it predicts, depend critically on three parameters that vary widely across Germany. The first represents potential income to the biogas plant, namely the gate fees an operator can charge for accepting Elodea. This depends on the community's willingness-to-pay the biogas operator instead of paying for current disposal services, a trade-off embedded in the local community context. The second two parameters represent business expenses: the cost of straw, when used in an Elodea-straw mix, and the disposal cost for digestate. While the cost for maize silage also influences our model, uncertainty here is less pronounced than for gate fees and the costs for straw and disposal.

In Fig. 5, we show how the additional cost per tonne of Elodea (only steps 4-8) vary depending on the gate fees. Even the Elodea-straw mix silage would become economically feasible were gate fees for Elodea to approach 100 Euro per tonne.

Figure 6 shows the effect of varying digestate disposal cost on the additional cost per tonne of Elodea used. The display distorts somewhat how different the sensitivities are between the two relations, that is, how different the slopes of the lines really are. We would have to extend the $x$-axis in Fig. 6 to five times its length to scale it (0-20) to the same range as Fig. $5(0-100)$. If you imagine that, you can see how flat the curve in Fig. 6 would become, showing that the model results' sensitivity to

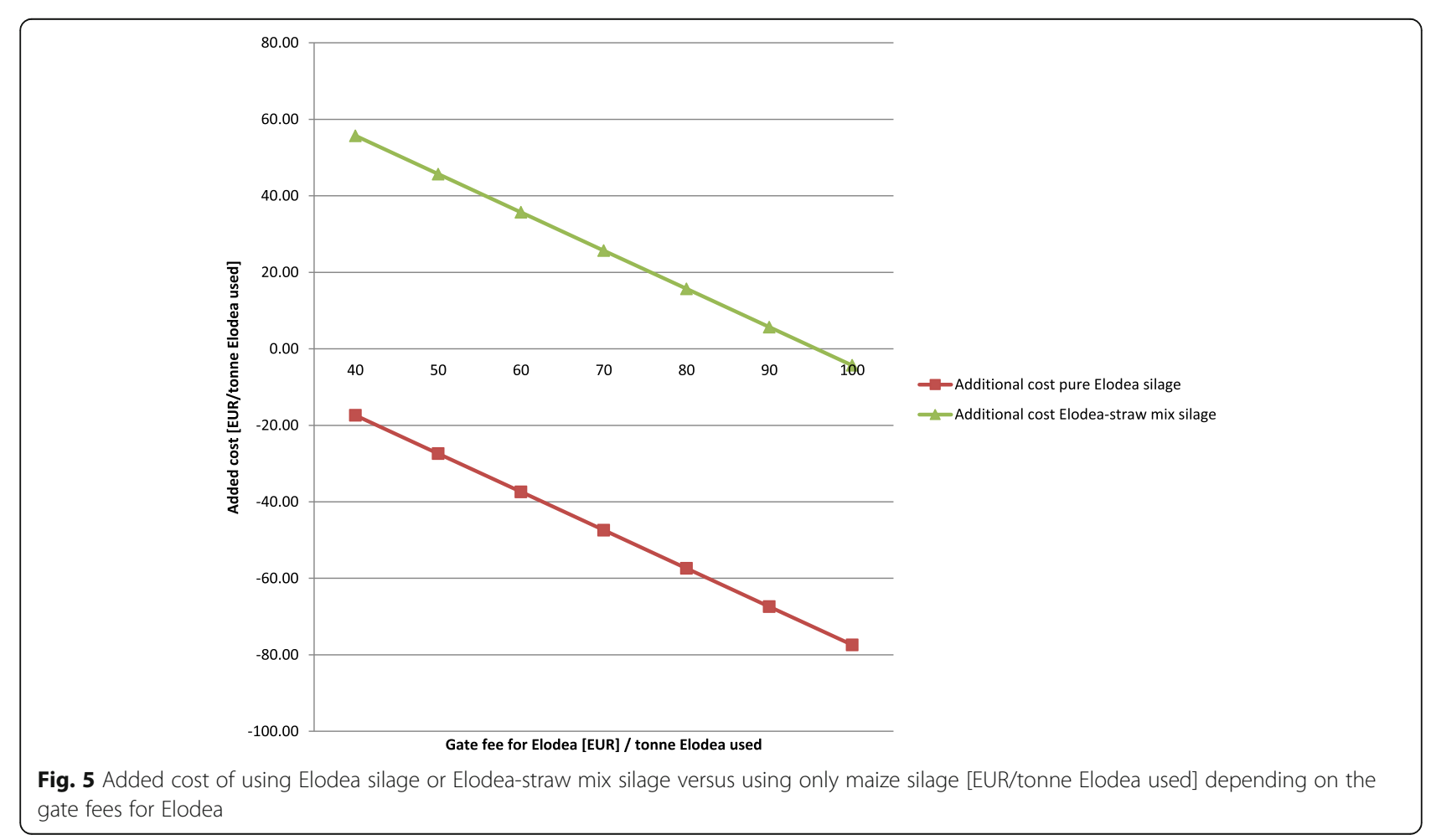




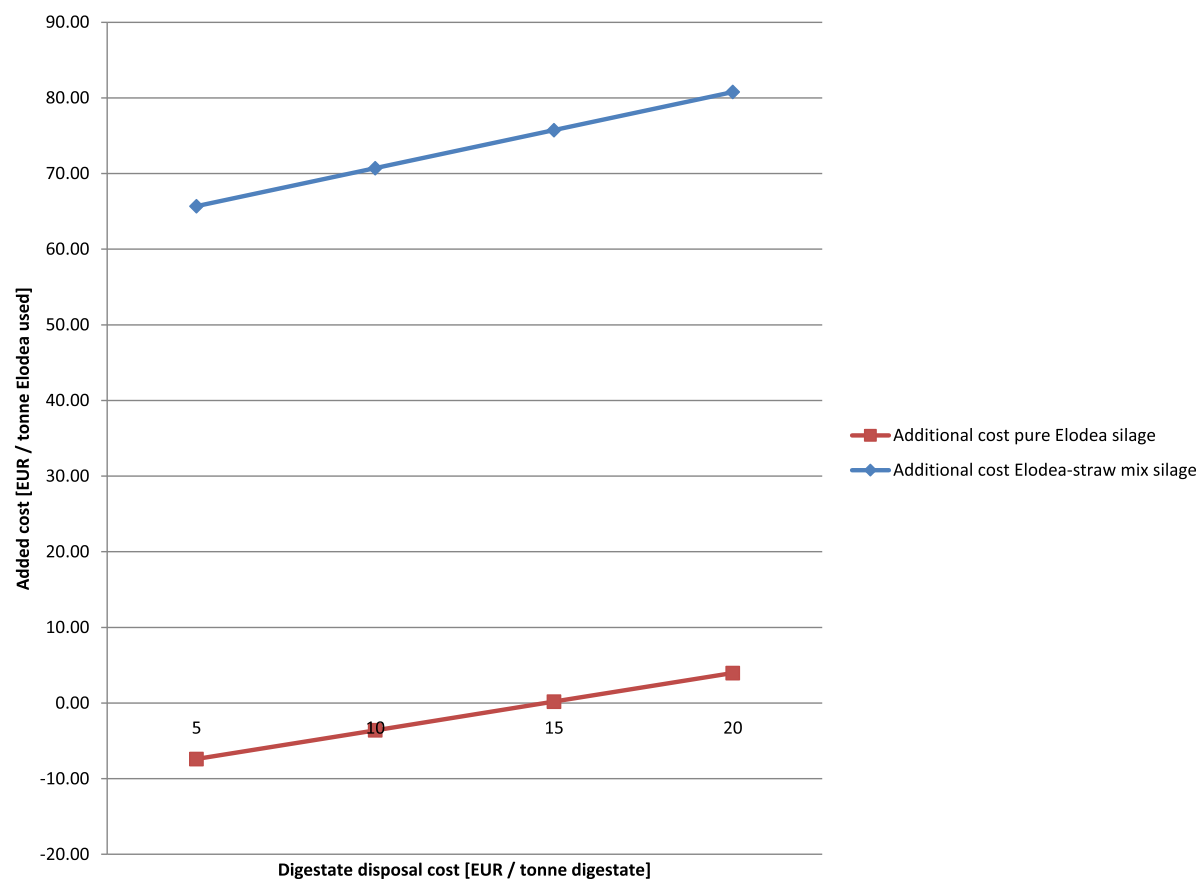

Fig. 6 Effect of varying digestate disposal cost on the additional cost per tonne of Elodea used

disposal costs is much less than its sensitivity to gate fees. Still, in regions with high disposal cost for digestate, even the $10 \%$ replacement of silage with Elodea (case 2) can become financially unattractive compared to using $100 \%$ maize silage (case 1 ).
Figure 7 depicts the effect of varying the cost of straw. If straw has to be purchased, regional prices apply; however, our model uses the national average. Moreover, if the biogas plant operator also runs a farm business, the straw can be produced in house at costs

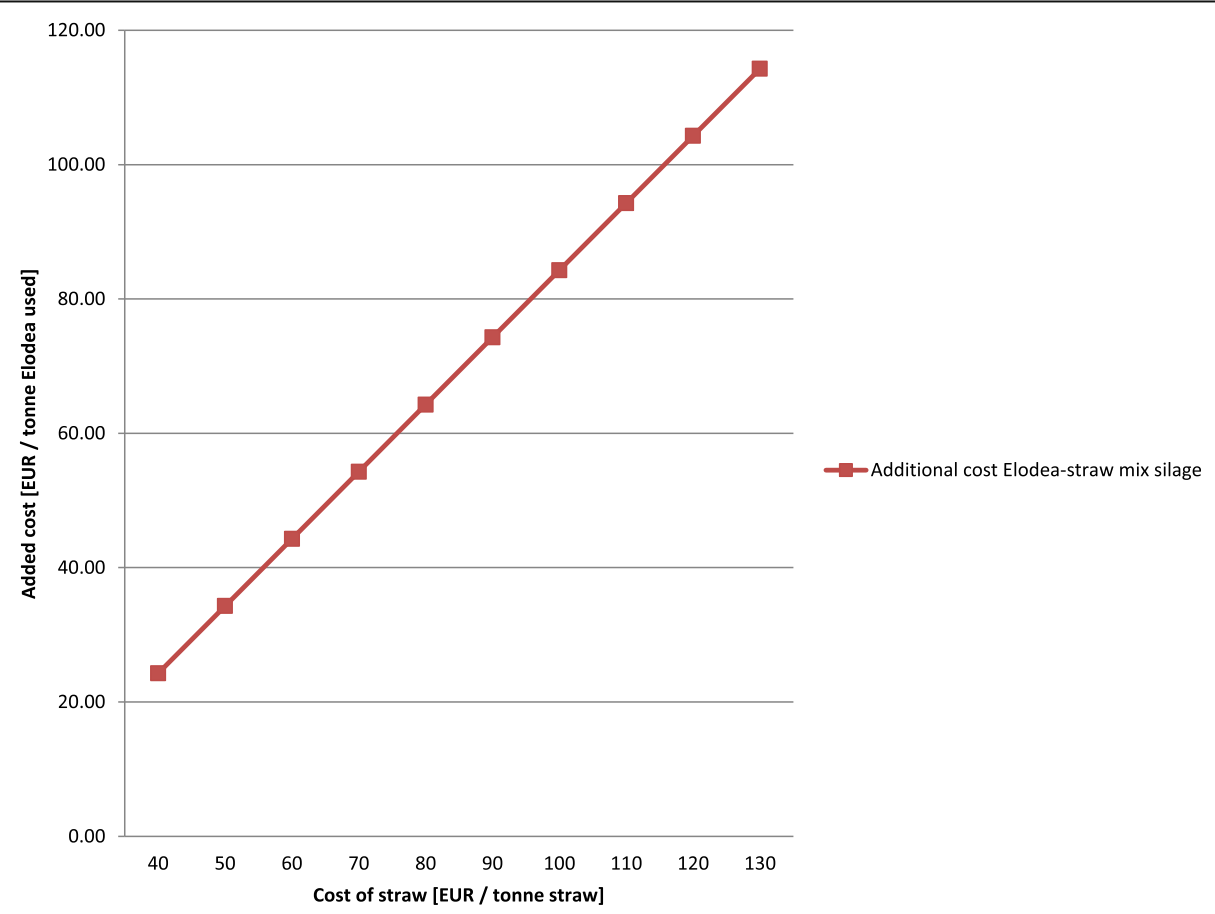

Fig. 7 Cost of using Elodea-straw mix silage compared to using only maize silage [EUR/tonne Elodea used] depending on the price for straw 
much lower than the market will deliver. That introduces the operator to an opportunity cost calculation: is it better to sell the straw or use it locally? For the purposes of our model, we consulted figures reported in the literature as a basis for extrapolation. Past research has calculated straw production costs, including transport and shredding, at around 40 Euro/tonne [46]. Figure 7 makes clear that even at production cost of 40 Euro/tonne, the cost of using water plants is still higher than that of using maize silage.

Figures 8 and 9 show the effects of changes in the different parameters for the two cases: pure Elodea (Fig. 8) and Elodea-straw mix silage (Fig. 9). For the latter, Fig. 9 makes clear that a change in the straw mix has the highest relative impact, followed by the gate fee and the disposal cost.

\section{Limitations}

The seven-step model introduced as the Aquatic Biomass Supply Chain in the "Methods" section of this paper serves as a realistic and useful framework for developing business plans. Nevertheless, its predictions are no better than the data used to make them. Limitations resulting from the use of the model in this study arise from the limitations in both the precision and availability of data. But the model is also to be understood as capturing dynamic realities that emerge more from local than from regional or national contexts; such is the nature of a biogas plant's relationship with its community. This means that local factors affect each step of the supply chain, as described in the following.

1. Cutting: The costs of cutting aquatic weeds are highly variable. Factors playing into the calculation are:

a. Area access. This includes transporting the equipment to the river or lake where it is needed as well as getting the equipment into and out of the water. Where it is not possible to reach the water with the trailer, specialized equipment has to be used such as an amphibious boat. These are generally smaller and/or slower than standard equipment and have higher capital costs.

b. Water-weed composition and abundance. Water weed growth depends on the local ecosystem and of course varies throughout the year. This means harvest predictions are highly unpredictable, and not simply in terms of raw volume of fresh matter per square kilometer of water surface. A further complication is the multitude of different water weeds growing in German rivers and lakes, each of which has a different dry-matter profile that affects its performance in a biogas plant [24].

c. Equipment: The cost of equipment varies widely depending on the type of equipment. Our model assumes that the mowing boat is expensed through lease payments; however, an operator may find capitalizing the cost and amortizing it through asset depreciation to be a more attractive business option.

2. Collecting: Collecting water weeds can be a difficult task depending both on area and on waterfront access. In a flowing river with adequate currents, a simple stationary collecting device is sufficient. In standing waters, another approach is needed, which today in practical terms means a dedicated collecting boat.

3. Transport: Transport costs reflect, perhaps more than any other element in our model, the unique characteristics of the local market and aquatic ecosystem. First, where in the supply chain is the biomass transported? In most cases, shredding and

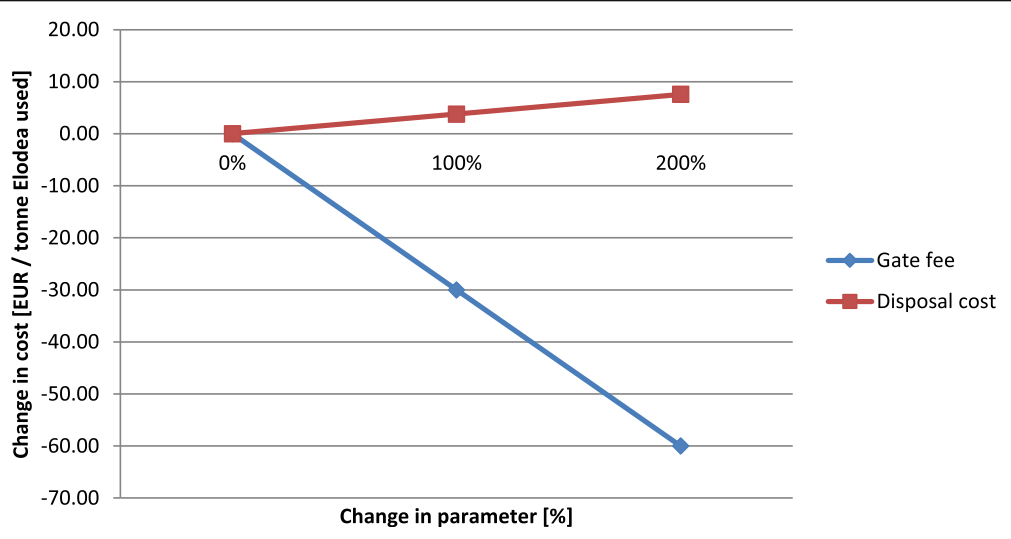

Fig. 8 Change in cost of using Elodea compared to using only maize silage [EUR/tonne Elodea used] depending on changes of gate fees for Elodea and disposal cost 


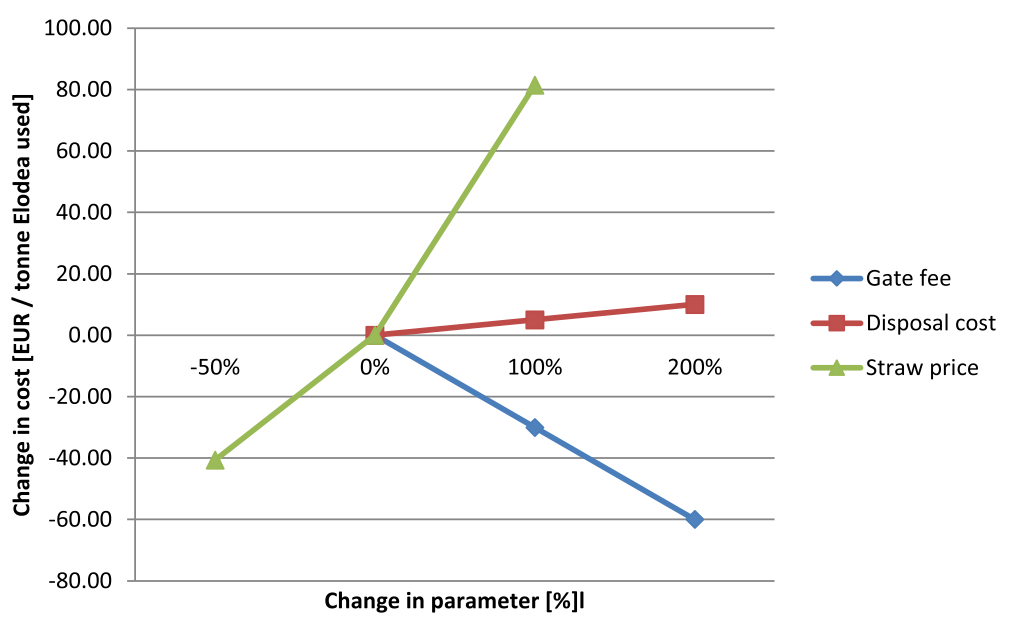

Fig. 9 Change in cost of using Elodea-straw mix silage compared to using only maize silage [EUR/tonne Elodea used] depending on changes of gate fees for Elodea, straw price, and disposal cost

ensiling the biomass is not possible directly at the waterfront, making it necessary to transport lowdensity fresh matter with a high water content. Second, many rivers and lakes are not accessible by road, making it difficult for standard trucks to reach the pickup sites, adding another variable to transport costs. Third, it is transport that connects the biogas plant to the local aquatic ecosystem; how far that line can stretch and still remain economically feasible defines the range of plant-ecosystem configurations possible in a community.

4. Treatment: The treatment of the raw material before feeding it into the fermenter is necessary to protect the fermenter and to ensure good fermentation. While we were able to show through a small-scale experiment that existing farming machinery is capable of shredding aquatic biomass, this cannot be assumed to hold for large-scale use.

5. Ensiling: As mentioned when discussing the supply chain, ensiling aquatic plants without adding material with a higher dry matter content is barely feasible. Further research could look into ensiling these materials using cheaper materials, thereby avoiding the costs of expensive straw. Maize straw might prove to be an interesting approach.

6. Fermentation: Our calculations assume that using aquatic macrophytes does not have any negative effects on the biogas plants beyond the change in HRT. However, using this material could result in reduced uptimes due to more frequent clogging of components such as feed screws or to faster wear of components. Practical tests in real biogas plants including a close monitoring of uptimes would be needed to obtain a data-based assessment.
7. Disposal: The disposal costs for raw aquatic biomass may be subject to factors almost third world in their arbitrariness. For example, it was reported in one municipality that disposal of aquatic biomass at a site outside the municipality where the trailer was registered would incur a higher tariff than it would were the trailer registered locally.

\section{Avenues for further research}

The uncertainties in price points that are already known to be dynamic and vary across region should not distract us from the potential upsides for the use of water plants in biogas processes. The fact that many aquatic macrophytes are rich in micronutrients opens opportunities for further increasing the economic attractiveness of this input material. Undersupply with micronutrients, especially nickel, molybdenum, and cobalt, can be a reason for suboptimal biogas yields [47] and there is abundant research proving the positive effects on biogas production of adding micronutrients to the process [48-52]. Biogas plants operating without manure, i.e., on monofermentation of energy crops, require regular addition of micronutrients [53-55]. In Germany, many biogas plants run on monofermentation and incur considerable cost for adding micronutrients. The analysis of aquatic macrophytes has shown that they are especially rich in molybdenum and manganese, which are also required in the biogas process [24]. It could be of great benefit to further explore the possible benefits aquatic macrophyte biomass could offer biogas plants running on monofermentation of energy crops. 


\section{Abbreviations}

DM: Dry matter content [\%]; FIT: Feed-in-tariff; FM: Fresh mass [kg]; HRT: Hydraulic retention time [days]; kW: Kilowatt; kWe: kW electric; OLR: Organic loading rate [kg VS/cbm/day]; REA: Renewable Energy Act; t: Tonne; TS: Total solids [\% FM]; VS: Volatile solids [\% TS]

\section{Acknowledgements}

The authors would like to thank Harald Wedwitschka and Walter Stinner from the German Biomass Research Center for providing data on the characteristics of Elodea silage and Elodea-straw mix silage and Andreas Zehnsdorf from the Helmholtz Centre for Environmental Research-UFZ for valuable input on the manuscript.

\section{Funding}

The investigations that form the basis for this article were carried out within the framework of the "Aquatic macrophytes-Optimal ecological and economic use" (AquaMak) research project. The "AquaMak" project is supported by the German Federal Ministry of Food, Agriculture and Consumer Protection with funds from the so-called Energy and Climate Funds (EKF) on the basis of a decision of the German Parliament (grant number: 22402014). The project partners are the Helmholtz Centre for Environmental Research-UFZ, Nürtingen-Geislingen University-HfWU, and the German Biomass Research Centre-DBFZ.

\section{Authors' contributions}

$\mathrm{CH}$ led the project at HfWU, did the literature review, built the model for calculating the effects on the fermentation process, and prepared the manuscript. VB assisted in collecting the data on the technical processes for cutting, collecting, transporting, and pre-treating the biomass and prepared the respective parts of the manuscript. MR and SR contributed to the critical reading of the manuscript, and provided input for the final version. All authors edited and approved the final manuscript.

\section{Authors' information}

$\mathrm{CH}$ is a professor and director of the "Institute for International Research on Sustainable Management and Renewable Energy" (ISR) at HfWU. VB is a former researcher at ISR. MR is a professor at HFWU and SR is a research assistant at ILU.

\section{Ethics approval and consent to participate}

Not applicable.

\section{Consent for publication}

Not applicable.

\section{Competing interests}

The authors declare that they have no competing interests.

\section{Publisher's Note}

Springer Nature remains neutral with regard to jurisdictional claims in published maps and institutional affiliations.

\section{Author details \\ 'Hochschule für Wirtschaft und Umwelt Nürtingen-Geislingen, Institute for International Research on Sustainable Management and Renewable Energy (ISR), Sigmaringer Strasse 14, 72622 Nürtingen, Germany. ${ }^{2}$ Hochschule für Wirtschaft und Umwelt Nürtingen-Geislingen, Institut für Landschaft und Umwelt (ILU), Sigmaringer Strasse 14, 72622 Nürtingen, Germany.}

Received: 7 February 2018 Accepted: 6 June 2018

Published online: 02 July 2018

\section{References}

1. European Biogas Association (2016) 17,358 biogas plants in Europe

2. German Biogas Association (2017) Biogas market data in Germany 2016/ 2017. German Biogas Association, Freising

3. Agency for Renewable Resources Bioenergy in Germany: Facts and Figures 2017, 4th edn. Guelzow.

4. Herbes C, Jirka E, Braun JP et al. (2014) Der gesellschaftliche Diskurs um den "Maisdeckel" vor und nach der Novelle des Erneuerbare-EnergienGesetzes (EEG) 2012 The Social Discourse on the "Maize Cap" before and after the 2012 Amendment of the German Renewable Energies Act (EEG). gaia(2/2014): 100-108. https://doi.org/10.14512/gaia.23.2.7

5. Zehnsdorf A, Hussner A, Eismann F et al. (2015) Management options of invasive Elodea nuttallii and Elodea canadensis. Limnologica-Ecology and Management of Inland Waters 51: 110-117. https://doi.org/10.1016/j.limno. 2014.12.010

6. Zehnsdorf A (2012) Aquatic neophytes as a substrate for biogas plants? In: Görke U-J, Thrän D, Messner F et al. (eds) First UFZ Energy Days 2012: Book of abstracts, Leipzig, p 15

7. Kshirsagar MP, Arora A, Chandra H (2012) Estimation of anaerobic codigestion potential of agri-waste in India and comparative financial analysis. Int J Sustainable Energy 31(3):175-188

8. Bacenetti J, Negri M, Lovarelli D et al (2015) Economic performances of anaerobic digestion plants: effect of maize silage energy density at increasing transport distances. Biomass Bioenergy 80:73-84

9. Karellas S, Boukis I, Kontopoulos G (2010) Development of an investment decision tool for biogas production from agricultural waste. Renew Sustain Energy Rev 14(4):1273-1282

10. Mueller S (2007) Manure's allure: variation of the financial, environmental, and economic benefits from combined heat and power systems integrated with anaerobic digesters at hog farms across geographic and economic regions. Renew Energy 32(2):248-256

11. Auburger S, Petig E, Bahrs E (2017) Assessment of grassland as biogas feedstock in terms of production costs and greenhouse gas emissions in exemplary federal states of Germany. Biomass Bioenergy 101:44-52

12. Gissén C, Prade T, Kreuger E et al (2014) Comparing energy crops for biogas production-yields, energy input and costs in cultivation using digestate and mineral fertilisation. Biomass Bioenergy 64:199-210

13. Di Corato L, Moretto M (2011) Investing in biogas: timing, technological choice and the value of flexibility from input mix. Energy Econ 33(6): 1186-1193

14. Auburger S, Jacobs A, Märländer B et al (2016) Economic optimization of feedstock mix for energy production with biogas technology in Germany with a special focus on sugar beets-effects on greenhouse gas emissions and energy balances. Renew Energy 89:1-11

15. Sgroi F, Foderà M, Di Trapani AM et al (2015) Economic evaluation of biogas plant size utilizing giant reed. Renew Sustain Energy Rev 49: 403-409

16. Stürmer B (2017) Feedstock change at biogas plants-impact on production costs. Biomass Bioenergy 98:228-235

17. Montingelli ME, Tedesco S, Olabi AG (2015) Biogas production from algal biomass: a review. Renew Sustain Energy Rev 43:961-972

18. Vulsteke E, van Den Hende S, Bourez L et al (2017) Economic feasibility of microalgal bacterial floc production for wastewater treatment and biomass valorization: a detailed up-to-date analysis of up-scaled pilot results. Bioresour Technol 224:118-129

19. Zamalloa C, Vulsteke E, Albrecht J et al (2011) The techno-economic potential of renewable energy through the anaerobic digestion of microalgae. Bioresour Technol 102(2):1149-1158

20. Santos-Ballardo D, Rossi S, Reyes-Moreno C et al (2016) Microalgae potentia as a biogas source: current status, restraints and future trends. Rev Environ Sci Biotechnol 15(2):243-264

21. Meyer MA, Weiss A (2014) Life cycle costs for the optimized production of hydrogen and biogas from microalgae. Energy 78:84-93

22. Röhl M, Roth S (2017) Biomassepotenziale submerser Makrophyten in Deutschland. In: Moeller L, Zehnsdorf A (eds) Wasserpflanzenmanagement, Leipzig, pp 6-12

23. Hashimoto AG (1983) Conversion of straw-manure mixtures to methane at mesophilic and thermophilic temperatures. Biotechnol Bioeng 25(1): 185-200. https://doi.org/10.1002/bit.260250115

24. Zehnsdorf A, Moeller L, Stärk H-J et al (2017) The study of the variability of biomass from plants of the Elodea genus from a river in Germany over a period of two hydrological years for investigating their suitability for biogas production. Energy. Sustain Soc 7(1):1-7

25. Milledge JJ, Harvey PJ (2016) Potential process 'hurdles' in the use of macroalgae as feedstock for biofuel production in the British Isles. Chem Technol Biotechnol 91(8):2221-2234. https://doi.org/10.1002/jctb. 5003

26. Herrmann C, FitzGerald J, O'Shea R et al (2015) Ensiling of seaweed for a seaweed biofuel industry. Bioresour Technol 196:301-313. https://doi.org/10. 1016/j.biortech.2015.07.098 
27. Wedwitschka H, Gießmann M et al (2017) In Mischung konservieren. In: Moeller L, Zehnsdorf A (eds). Wasserpflanzenmanagement, Leipzig, pp 26-31

28. Dębowski M, Zieliński M, Dudek M et al (2016) Acquisition feasibility and methane fermentation effectiveness of biomass of microalgae occurring in eutrophicated aquifers on the example of the Vistula Lagoon. Int J Green Energy 13(4):395-407

29. Dahlin J, Nelles M, Herbes C (2017) Biogas digestate management: evaluating the attitudes and perceptions of German gardeners towards digestate-based soil amendments. Resour Conserv Recycl 118:27-38

30. Dahlin J, Herbes C, Nelles M (2015) Biogas digestate marketing: qualitative insights into the supply side. Resour Conserv Recycl 104:152-161

31. Podraza P, Brinkmann T, Evers P, von Felde D, Frost U, Klopp R, Knotte $H$, Kühlmann M, Kuk M, Lipka P, Nusch EA, Stengert M, Wessel M, van de Weyer K (2008) Untersuchungen zur Massenentwicklung von Wasserpflanzen in den Ruhrstauseen und Gegenmaßnahmen. Final report, research project for the Ministry of Environment and Conservation, Agriculture and Consumer Protection of the Federal State of North Rhine Westphalia (MUNLV)

32. Dahlhoff A (2007) Auswirkungen einer erhöhten Faulraumbelastung auf die Prozessbiologie bei der Vergärungnachwachsender Rohstoffe in landwirtschaftlichen Biogasanlagen: Untersuchung unter besonderer Berücksichtigungder aktuellen Situation der Biogasproduktion in NordrheinWestfalen. Doctoral Dissertation, Goettingen University

33. Menardo S, Gioelli F, Balsari P (2011) The methane yield of digestate: effect of organic loading rate, hydraulic retention time, and plant feeding. Bioresour Technol 102(3):2348-2351. https://doi.org/10.1016/j. biortech.2010.10.094

34. Gemmeke B, Rieger C, Weiland P et al. (2010) Biogas-Messprogramm II: 61 Biogasanlagen im Vergleich, FNR, Gülzow

35. Lehner A, Effenberger M, Gronauer A (2010) Optimierung der VerfahrenstechniklandwirtschaftlicherBiogasanlagen. LfL-Schriftenreihe, Freising

36. Schulz M (2017) Supplying process of aquatic macrophytes for biogas production. Master Thesis, University of Applied Sciences Zwickau

37. (2017) KTBL Feldarbeitsrechner. KTBL, Darmstadt https://daten.ktbl.de/ feldarbeit/entry.html

38. Schulze Steinmann M, Holm-Muller K (2010) Thunensche Ringe der Biogaserzeugung-Der Einfluss der Transportwurdigkeit nachwachsender Rohstoffe auf die Rohstoffwahl von Biogasanlagen. (Thuenen rings of biogas production-the effect of differences in transport costs of energy crops in the choice of renewable resources by biogas plants. With English summary.). German. J Agric Econ 59(1):1-12

39. Tedesco S, Benyounis KY, Olabi AG (2013) Mechanical pretreatment effects on macroalgae-derived biogas production in co-digestion with sludge in Ireland. Energy 61:27-33

40. Taherzadeh JM, Karimi K (2008) Pretreatment of lignocellulosic wastes to improve ethanol and biogas production: a review. Int J Mol Sci 9:1621-1651

41. Carlsson M, Lagerkvist A, Morgan-Sagastume F (2012) The effects of substrate pre-treatment on anaerobic digestion systems: a review. Waste Manag 32(9):1634-1650. https://doi.org/10.1016/j.wasman.2012.04.016

42. KTBL (2017) Betriebsplanung Landwirtschaft 2016/17, 25. Auflage, Darmstadt

43. Rößl G, Wagner A (2010) Schlauchsilierung -Verfahrensbeschreibung und Bewertung

44. Pecenka R, Idler C, Grundmann P et al (2007) Tube ensiling of hemp_initial practical experience. Agric Eng Res 13(1):15-26

45. Wiesheu M (2017) Alternative Substrate für Biogasanlagen. In: Moeller L Zehnsdorf A (eds). Wasserpflanzenmanagement, Leipzig, pp 43-49

46. Stinner W, Schmalfuß T, Döhler H et al. Kann die Vergärung von Stroh ökonomisch sinnvoll sein?

47. Wan C, Zhou Q, Fu G et al (2011) Semi-continuous anaerobic co-digestion of thickened waste activated sludge and fat, oil and grease. Waste Manag 31(8):1752-1758. https://doi.org/10.1016/j.wasman.2011.03.025

48. Narra M, Balasubramanian V, Kurchania A et al (2016) Enhanced biogas production from rice straw by selective micronutrients under solid state anaerobic digestion. Bioresour Technol 220:666-671. https://doi.org/10. 1016/j.biortech.2016.09.027

49. Menon A, Wang J-Y, Giannis A (2017) Optimization of micronutrient supplement for enhancing biogas production from food waste in twophase thermophilic anaerobic digestion. Waste Manag 59:465-475. https:// doi.org/10.1016/j.wasman.2016.10.017
50. Juntupally S, Begum S, Allu SK et al (2017) Relative evaluation of micronutrients (MN) and its respective nanoparticles (NPs) as additives for the enhanced methane generation. Bioresour Technol 238:290-295. https:// doi.org/10.1016/j.biortech.2017.04.049

51. Pobeheim H, Munk B, Johansson J et al (2010) Influence of trace elements on methane formation from a synthetic model substrate for maize silage. Bioresour Technol 101(2):836-839. https://doi.org/10.1016/j. biortech.2009.08.076

52. Pobeheim $H$, Munk B, Lindorfer $H$ et al (2011) Impact of nickel and cobalt on biogas production and process stability during semi-continuous anaerobic fermentation of a model substrate for maize silage. Water Res 45(2):781-787. https://doi.org/10.1016/j.watres.2010.09.001

53. Nges IA, Escobar F, Fu X et al (2012) Benefits of supplementing an industrial waste anaerobic digester with energy crops for increased biogas production. Waste Manag 32(1):53-59. https://doi.org/10.1016/j. wasman.2011.09.009

54. Lübken M, Koch K, Gehring T et al (2015) Parameter estimation and long-term process simulation of a biogas reactor operated under trace elements limitation. Appl Energy 142:352-360. https://doi.org/10.1016/j. apenergy.2015.01.014

55. Lindorfer $H$, Ramhold D, Frauz B (2012) Nutrient and trace element supply in anaerobic digestion plants and effect of trace element application. Water Sci Technol 66(9):1923-1929. https://doi.org/10.2166/ wst.2012.399

56. Calise F, Cremonesi C, GN di Vastogirardi et al. (2015) Technical and economic analysis of a cogeneration plant fueled by biogas produced from livestock biomass. Energy Procedia 82: 666-673. https://doi.org/10. 1016/j.egypro.2015.12.024

57. Wirth B, Hartmann S (2013) Assessing concepts for utilising heat from biogas plants. Landtechnik 68(3):202-207

58. Watkins P, McKendry P (2015) Assessment of waste derived gases as a renewable energy source - part 1. Sustainable Energy Technol Assess 10: 102-113. https://doi.org/10.1016/j.seta.2015.03.001

59. Kimming M, Sundberg $C$, Nordberg $\AA$ et al (2011) Biomass from agriculture in small-scale combined heat and power plants-a comparative life cycle assessment. Biomass Bioenergy 35(4):1572-1581

60. Havukainen J, Uusitalo V, Niskanen A et al (2014) Evaluation of methods for estimating energy performance of biogas production. Renew Energy 66:232-240

61. Patrizio P, Leduc S, Chinese D et al (2015) Biomethane as transport fuel-a comparison with other biogas utilization pathways in northern Italy. Appl Energy 157:25-34. https://doi.org/10.1016/j.apenergy.2015.07.074

62. Fachagentur Nachwachsende Rohstoffe e.V. (2017) Faustzahlen. https:// biogas.fnr.de/daten-und-fakten/faustzahlen/

63. Witte TD (2012) Entwicklung eines betriebswirtschaftlichen Ansatzes zur Exante-Analyse von Agrarstrukturwirkungen der Biogasförderung: Angewendet am Beispiel des EEG 2009 in Niedersachsen. Landbauforschung Sonderheft, vol 366. vTI, Braunschweig

64. Effenberger M, Bachmaier H, Kränsel E et al (2010) Wissenschaftliche Begleitung der Pilotbetriebe zur Biogasproduktion in Bayern. In: LfL-Schriftenreihe

65. Hu W, Schmidt RJ, McDonell EE et al (2009) The effect of Lactobacillus buchneri 40788 or Lactobacillus plantarum MTD-1 on the fermentation and aerobic stability of corn silages ensiled at two dry matter contents. J Dairy Sci 92(8):3907-3914. https://doi.org/10.3168/jds.2008-1788

66. Khan NA, Cone JW, Fievez V et al (2012) Causes of variation in fatty acid content and composition in grass and maize silages. Anim Feed Sci Technol 174(1-2):36-45. https://doi.org/10.1016/j.anifeedsci.2012.02.006

67. Weissbach $\mathrm{F}$ (2008) On assessing the gas production potential of renewable primary products. Landtechnik 63:356-358

68. Bayerische Landesanstalt für Landwirtschaft (2017) Biogasausbeuten verschiedener Substrate. http://www.Ifl.bayern.de/iba/energie/049711/?sel_ list=12\%2Cb\&anker0=substratanker\#substratanker

69. Stürmer B, Schmid E, Eder MW (2011) Impacts of biogas plant performance factors on total substrate costs. Biomass Bioenergy 35(4):1552-1560. https:// doi.org/10.1016/j.biombioe.2010.12.030

70. Deutsches Biomasseforschungszentrum (2015) Stromerzeugung aus Biomasse (Vorhaben Ila Biomasse): Zwischenbericht Mai 2015, Leipzig

71. KTBL (2017) Vergütungsrechner für Strom aus Biogas. KTBL, Darmstadt

72. Bartoli A, Cavicchioli D, Kremmydas D et al (2016) The impact of different energy policy options on feedstock price and land demand for maize silage: the case of biogas in Lombardy. Energy Policy 96:351-363. https://doi.org/ 10.1016/j.enpol.2016.06.018 
73. Igliński B, Buczkowski R, Iglińska A et al (2012) Agricultural biogas plants in Poland: investment process, economical and environmental aspects, biogas potential. Renew Sust Energ Rev 16(7):4890-4900. https://doi.org/10.1016/j. rser.2012.04.037

74. Krauß H (2017) Preise: Soviel kostet die Tonne Stroh. https://www. agrarheute.com/analysen-kommentare/preise-soviel-kostet-tonne-stroh

75. Rutz D, Mergner R et al (2015) Sustainable Heat Use of Biogas Plants: A handbook, 2nd edn

76. Brauckmann H-J (2011) Nährstoffstromanalyse einer Biogasanlage, Verden

77. Gebrezgabher SA, Meuwissen MPM, Prins BAM et al (2010) Economic analysis of anaerobic digestion-a case of green power biogas plant in the Netherlands. NJAS - Wageningen Journal of Life Sciences 57(2):109115. https://doi.org/10.1016/j.njas.2009.07.006

78. Walla C, Schneeberger W (2008) The optimal size for biogas plants. Biomass Bioenergy 32(6):551-557. https://doi.org/10.1016/j.biombioe.2007.11.009

79. Goulding D, Power N (2013) Which is the preferable biogas utilisation technology for anaerobic digestion of agricultural crops in Ireland: biogas to CHP or biomethane as a transport fuel? Renew Energy 53:121-131. https:// doi.org/10.1016/j.renene.2012.11.001

80. Poeschl M, Ward S, Owende P (2010) Prospects for expanded utilization of biogas in Germany. Renew Sust Energ Rev 14(7):1782-1797

81. Döring G, Schilcher A, Strobl M et al. (2010) Verfahren zum Transport von Biomasse

82. Mitterleitner H, Schilcher A, Demmel M (2007) NawaRo-Transport: Konzepte zur Reduzierung der Kosten beim Transport von nachwachsenden Rohstoffen für Biogasanlagen, Freising

83. Handler F, Blumenauer E (2008) Beschaffungs- und Distributionslogistik bei großen Biogasanlagen. Biogastagung Juni 2008, Innsbruck

84. Weber U, Kaiser E, Steinhöfel O (2006) Studies on ensiling pressed sugarbeet pulp in plastic tubes: Part 1: Effect of delayed ensiling (24 hours interposed storage) on feeding value, losses and silage quality; costs of tube ensiling. Sugar Industry 131(10):691-697

85. Hartmann S, Döhler H (2011) The economics of sugar beets in biogas production. Landtechnik 4:250-253

\section{Submit your manuscript to a SpringerOpen ${ }^{\circ}$ journal and benefit from:}

- Convenient online submission

- Rigorous peer review

- Open access: articles freely available online

- High visibility within the field

- Retaining the copyright to your article

Submit your next manuscript at $\boldsymbol{s p r i n g e r o p e n . c o m ~}$ 